University of South Carolina

Scholar Commons

1984

\title{
A Probabilistic Approach to the Spatial Assessment of River Channel Instability
}

William L. Graf

University of South Carolina-Columbia, grafw@mailbox.sc.edu

Follow this and additional works at: https://scholarcommons.sc.edu/geog_facpub

Part of the Geography Commons

\section{Publication Info}

Published in Water Resources Research, Volume 20, Issue 7, 1984, pages 953-962.

http://www.agu.org/journals/wr/

(c) 1984 by American Geophysical Union

This Article is brought to you by the Geography, Department of at Scholar Commons. It has been accepted for inclusion in Faculty Publications by an authorized administrator of Scholar Commons. For more information, please contact digres@mailbox.sc.edu. 


\title{
A Probabilistic Approach to the Spatial Assessment of River Channel Instability
}

\author{
William L. GraF \\ Department of Geography, Arizona State University, Tempe
}

\begin{abstract}
The deterministic approach to the analysis of river channel instability has not proved to be a completely useful basis for geographic predictions of channel behavior. Economic estimates for benefits of structural channel control projects commonly account for flood inundation, but in arid and semiarid regions these estimates are incomplete because they fail to take into account destructive channel migration and erosion. As a solution, a method whereby historical records of channel locations are reduced to spatially defined probabilistic functions allows calculation of the probability that given parcels of nearchannel terrain will be destroyed by erosion. The probability of erosion for any given parcel over a given period of time is directly proportional to the sizes of the annual floods during the period and inversely proportional to two distance measures: distance upstream and distance laterally to the channel. In a test of the probabilistic geographic method using data on the locations of Rillito Creek, Arizona, from 1871 to 1978 , erosion probability maps accurately characterized the locations of observed changes. In a 50 -year simulated period, erosion ultimately produced economic losses that were 5 times greater than potential inundation losses.
\end{abstract}

\section{Problem Statement}

A major complication in prediction of the behavior of arid region rivers is that deterministic engineering, hydrologic, and geomorphologic models relying on deductive approaches are aspatial. Because they are based on cross-section specific approaches, they are generally ineffective in predicting the exact nature and location of channel migration and resulting erosion damage (as a relevant specific example, see Simons, $L i$ and Associates, [1981]; for general methods see Simons and Senturk [1977] and Shen [1979]). Fluvial processes are so complex that it is unlikely that precise predictions are possible in any case, but alternative approaches utilizing a probabilistic geographic approach may provide enhanced predictive capabilities. A major lesson of channel stabilization projects in the United States has been the importance of understanding overall stream behavior before project efforts begin [Corps of $E n$ gineers, 1981, p. 2]. Unfortunately, fluvial theories and data have little to offer in the planimetric analysis of channel erosion [Hughes, 1977].

Practically, the accurate prediction of probable erosion caused by uncontrolled channel migration is essential to useful evaluation of expected benefits from structural control efforts. Benefits include expected damages under a "no project" alternative that can be prevented by the anticipated project. Benefits are then compared to expected project costs before a final planning decision. A successful evaluation of the probable course of events in the case of no project can be accomplished for perennial streams of humid regions by determining the likely frequency of overbank flows and then attaching an economic valuation to inundated properties and disrupted activities. In arid and semiarid regions, however, such an approach fails to take into account flood-related damages resulting from bank erosion and channel migration, common characteristics of ephemeral streams. Therefore assessments of likely damages that rely on an analysis of inundation alone may provide seriously underestimated values.

Copyright 1984 by the American Geophysical Union.

Paper number $4 \mathrm{~W} 0320$.

0043-1397/84/004W-0320\$05.00
The objectives of the following paper are twofold. First, geographic, geomorphic, hydrologic, and statistical techniques are combined to produce a probabilistic method of characterizing planimetric channel instability. Second, a brief case study of Rillito Creek near Tucson, Arizona, provides a demonstration of probabilistic method of erosion damage assessment and reveals some geographic aspects of fluvial processes in a semiarid area.

\section{Method of Spatial ANalysis}

A probabilistic analysis of future channel locations logically begins with an analysis of past locations. Historical maps, aerial photographs, and engineering surveys provide data on channel locations, but when these locations are plotted on a topographic base map, their overlapping courses provide a confusing picture. Analysis is simplified if the basic maps are converted to cells of a standard size and shape. In the present study these cells are squares $100 \mathrm{~m}$ (328 ft) on a side, but they could also be triangles, hexagons, or rectangles. Each cell can be designated as "channel" or "nonchannel" for any particular time period, with erosion of a cell indicated by a change from nonchannel to channel. Deposition or channel filling is indicated by a reverse change, but it is not addressed in this study.

There are three important advantages of using a map of cells: statistical properties, related published research, and ease of computerization. In a map of cells, each individual cell has a unique set of statistical properties based on its location. Its absolute location can be evaluated as a distance east and north of an arbitrary initial cell with the distance expressed in some standard unit of measure or simply as a number of cells. Relative distances can be similarly expressed, for example, a distance in number of cells to the nearest cell with a channel. Absolute and relative distances, combined with specific orientations such as lateral or upstream with respect to existing channels, are basic inputs in any spatial analysis of the nearchannel system.

A second advantage in the use of cellular maps is that the distances from a given cell to a point of interest and a value for the given cell (a value representing probability of erosion, for example) are susceptible to analysis similar to that known as spatial autocorrelation (reviewed by Cliff and Ord [1981]). 


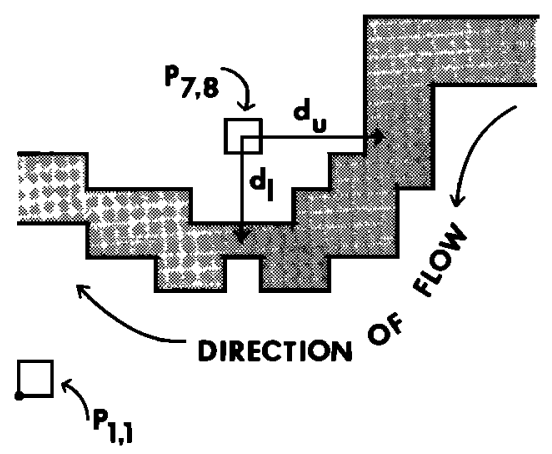

Fig. 1. A schematic diagram of a cell map. Cell $P_{i, j}$ is the arbitrary origin cell; cell $P_{7,8}$ is located seven cells east and eight cells north of the origin. Shaded cells represent the channel, while $d_{t}$ is the lateral distance from cell $P_{7,8}$ to the channel and $d_{v}$ is the upstream distance.

The concepts of spatial autocorrelation flow from the basic assumption of geographic analysis that is also the basis of the present study: There is a systematic (usually exponential) decline in neighboring influence as distance increases. Applications of this concept of "potential" in the social sciences have some promise, but problems occasionally arise because of unsound theoretical support [Sheppard, 1979]. Applications in fluvial theory development have proven useful for analysis of dispersion of pollutants [Glover, 1964] and the spatial development of arroyos [Graf, 1982].

A third major advantage of the cellular maps is ease of conversion to computerized analysis. Multidimensional matrix programming can convert the cartographic map to a mathematical map, with each cell represented by an ordered pair $(x, y)$ representing the absolute cell location measured from an arbitrary initial cell. Relative distances to specified points of interest such as channels and particular values such as probability of erosion or property values can then be attached to the ordered pair and the cell that the pair represents.

A review of the fluvial geomorphic literature (see Gregory [1977] for a recent example) suggests that the probability that any limited section of the near-channel surface (such as a cell) will be eroded during a particular time period is dependent on its location with respect to the active channel and the magnitudes and frequencies of floods during the period in question. Location of each cell with respect to the active channel is most important in the lateral and upstream directions, as in the case of a meander being located upstream from a cell (Figure 1). The magnitudes of the annual floods during the period of interest (empirical if a past observed period or simulated if a future predicted period) can be assessed by the sum of their recurrence intervals. Therefore the probability that a given cell will be eroded by the channel in a limited time period is

$$
P_{i, j}=f\left(d_{l}, d_{w}, \sum_{t=1}^{n} r\right)
$$

where $P_{i, j}$ is the probability of erosion $\left(0 \leq P_{i, j} \leq 1\right)$, for a given cell located at coordinates $i, j ; f$ is a function; $d_{l}$ is the distance laterally across the floodplain from the cell to the nearest active channel cell; $d_{u}$ is the distance upstream along the floodplain to the nearest active channel; $r$ is the return interval of a peak annual flood, $t$ is a year, and $n$ is the number of years in the period of interest.

The appropriate form for function $f$ is probably a multiple power function because in previous fluvial research distance terms have been shown to be related to magnitudes by power functions (summarized by Leopold et al. [1964]). Fluvial process and discharge measures are also commonly related by power functions, so that the likely form of (1) is

$$
P_{i, j}=a_{0}\left(d_{l}\right)^{b_{1}}\left(d_{u}\right)^{b_{2}}\left(\sum_{t=1}^{n} r\right)^{b_{3}}
$$

where $a_{0}$ and $b_{1,2,3}$ are empirically derived constants based on the historical record. For experimental purposes the constants can also be artificially manipulated. For purposes of application the values of $P_{i, j}$ are limited to the range $0.00-0.95$, though further experimentation may reveal a function form that asymptotically approaches 1.00 . In the present study no values exceeded 0.90 .

Given empirical observations for $P_{i, j}, d_{l}, d_{u}$, and $r$, equation (2) can be converted to its linear form

$$
\begin{aligned}
\log _{10} P_{i, j}=\log _{10} a_{0}+b_{1}\left(\log _{10} d_{l}\right) & +b_{2}\left(\log _{10} d_{u}\right) \\
& +b_{3}\left(\log _{10} \sum_{t=1}^{n} r\right)
\end{aligned}
$$

and the constants determined using standard least squares techniques. Empirical values for ordered sets of $\left(P_{i, j}, d_{l}, d_{w}\right.$, $\left.\sum_{t=1}^{n} r\right)$ can be obtained from transition matrices which are tables of the form shown in Table 1.

The transition matrix, made up of columns based on the lateral distance from a cell to the channel and rows based on the lateral distance from a cell to the channel, summarizes the statistical characteristics of all nonchannel cells for a particular time period. For example, in Table 1 (which is the transition matrix for Lower Rillito Creek for 1918-1937), 0.51 of all the cells located $100 \mathrm{~m}$ downstream and $100 \mathrm{~m}$ laterally from a channel at the beginning of the period were ultimately eroded and destroyed. If the sum of the return intervals of the annual floods during the period in question is 132 (the sum for 1918-1937), the ordered set for cells $100 \mathrm{~m}$ downstream and $100 \mathrm{~m}$ laterally from the channel is $(0.51,100,100,132)$.

The number of cells that classify themselves into the various column/rows of the transition matrix depends on channel geometry. If the channel is perfectly straight through the reach under analysis, observations will appear only in the final column because no map cells will have a channel cell up-

\begin{tabular}{|c|c|c|c|c|c|}
\hline \multirow{2}{*}{$\begin{array}{c}\text { Lateral } \\
\text { Distance, } \mathrm{m}\end{array}$} & \multirow[b]{2}{*}{ Statistic } & \multicolumn{4}{|c|}{ Upstream Distance, m } \\
\hline & & 100 & 200 & 300 & $400+$ \\
\hline \multirow[t]{3}{*}{100} & $c$ & 59 & 20 & 23 & 78 \\
\hline & $c_{e}$ & 30 & 3 & 13 & 9 \\
\hline & $P_{\mathrm{s}, \mathrm{j}}$ & 0.51 & 0.15 & 0.57 & 0.12 \\
\hline \multirow[t]{3}{*}{200} & $c$ & 0 & 6 & 15 & 89 \\
\hline & $c_{e}$ & 0 & 2 & 2 & 2 \\
\hline & $\boldsymbol{P}_{i, j}$ & 0.00 & 0.33 & 0.13 & 0.02 \\
\hline \multirow[t]{3}{*}{300} & $c$ & 0 & 0 & 7 & 29 \\
\hline & $c_{e}$ & 0 & 0 & 1 & 0 \\
\hline & $P_{i, j}$ & 0.00 & 0.00 & 0.14 & 0.00 \\
\hline \multirow[t]{3}{*}{400} & $c$ & 0 & 0 & 0 & 11 \\
\hline & $c_{e}$ & 0 & 0 & 0 & $\mathbf{0}$ \\
\hline & $\boldsymbol{P}_{i, j}$ & 0.00 & 0.00 & 0.00 & 0.00 \\
\hline
\end{tabular}
stream. If a radically meandering channel characterizes the

TABLE 1. Transition Matrix, Lower Rillito Creek, 1918-1937 $\left(\sum_{i=1}^{n} r=132\right)$

Here $c$ is the total number of cells with indicated distances; $c_{e}$ is the total number of cells eroded during the period, and $P_{t, j}$ is the observed probability of erosion, $c_{e} / c$. 


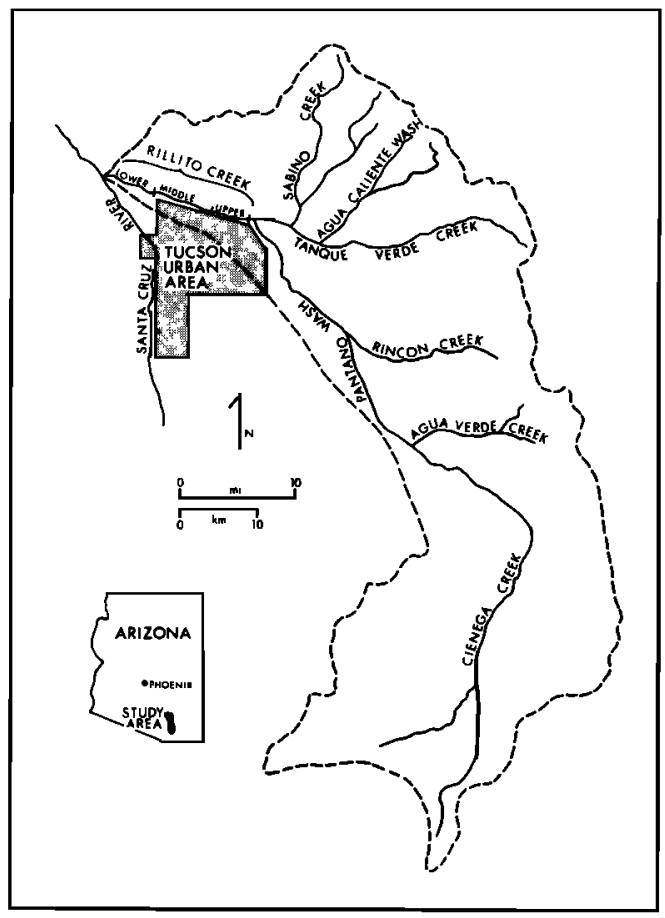

Fig. 2. Location of Rillito Creek. Based on U.S. Geological Survey $1: 250,000$ scale topographic maps.

reach under analysis, observations will appear in all the columns/rows. Because natural rivers usually have geometric characteristics between these two extremes, they are likely to produce matrices without observations in the lower left corner.

Each period of analysis (lasting a few years, usually determined by the availability of data) can produce a transition matrix containing several ordered sets of $\left(p_{i, j}, d_{l}, d_{u}, \sum_{t=1}^{n} r\right)$. Taken together, the ordered sets from several periods can supply the data to analyze (3) by least squares methods to determine empirically the values of $a_{0}$ and $b_{1,2,3}$. Assuming that the observed percentages of eroded cells are reasonable indicators of the probability of erosion in the future for similarly situated cells, the resulting function with defined coefficient and exponents can be used for any beginning situation. Calculations of probability of erosion can be made for a variety of time spans by manipulating the values input for the sum of the annual flood return intervals. The function can generate a new transition matrix for future changes, and the number of cells of each observed locational type can be multiplied by the appropriate probability to predict the number of cells likely to be eroded over the given period. The probabilities for the cells can also be mapped to represent the spatial variability of the probability of erosion.

\section{Algorithm}

An algorithm, a set of prescribed ordered steps in the solution of a problem, provides a detailed summary of the probabilistic approach to the geographic assessment of channel instability.

1. Map by conventional means from historical sources the past locations of the channel.

2. Convert the maps to fields of cells and designate those cells occupied by channel.

3. Begin analysis with one map representing the situation for a particular year. For those cells that are not occupied by channel, evaluate the lateral distance to the nearest cell with a channel and the upstream distance to the nearest cell with a channel. Lateral and upstream directions are determined by the direction of flow through the nearest channel-occupied cell.

4. Continue the analysis by examining a cellular map for a subsequent situation, perhaps 5 or 10 years after the first map. Designate the cells on the earlier map that began the period without channels but that were subsequently eroded.

5. In a transition matrix that represents change through

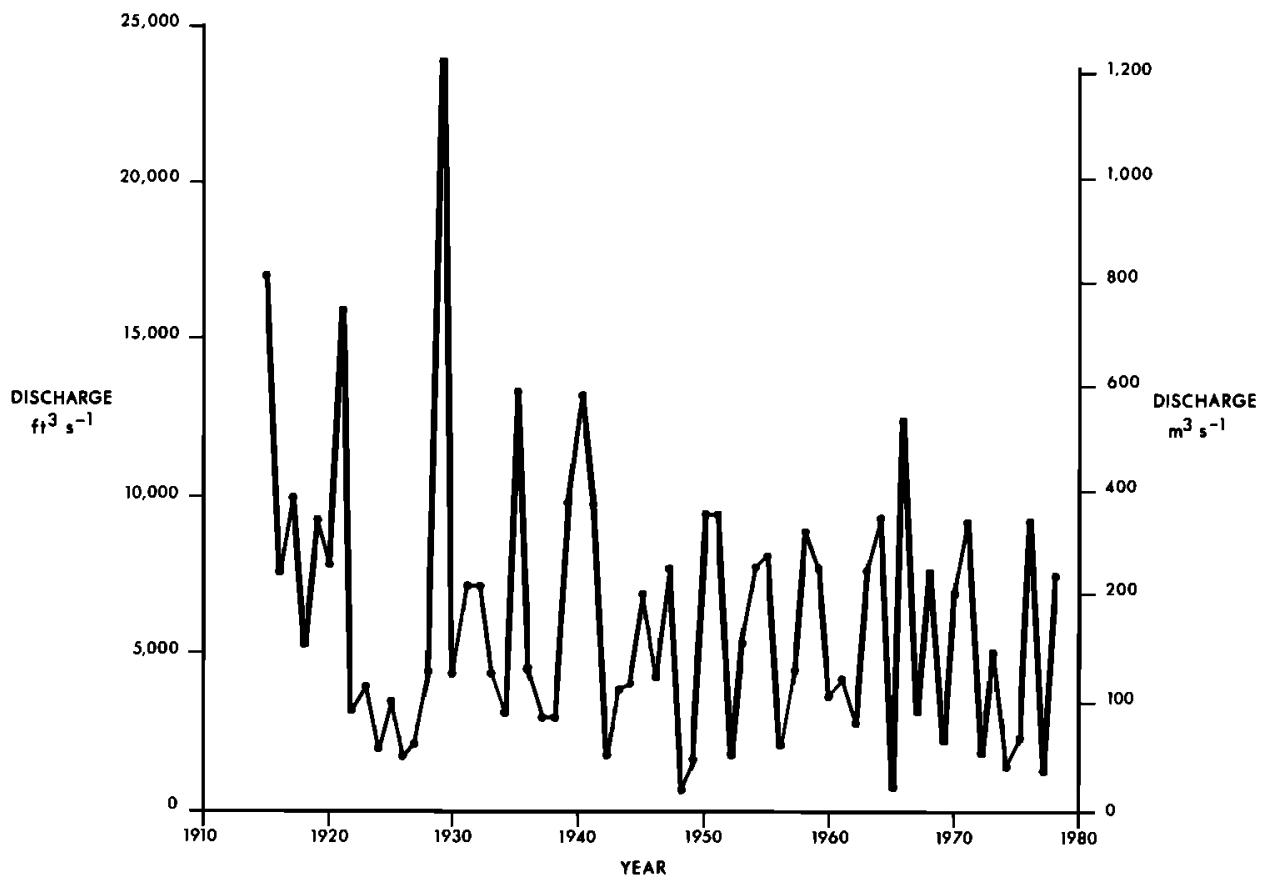

Fig. 3. Annual flood series for Rillito Creek. Data from a gauge located $6.6 \mathrm{~km}$ (4 mi) upstream from the confluence with the Santa Cruz River, published in U.S. Geological Survey water supply papers. 

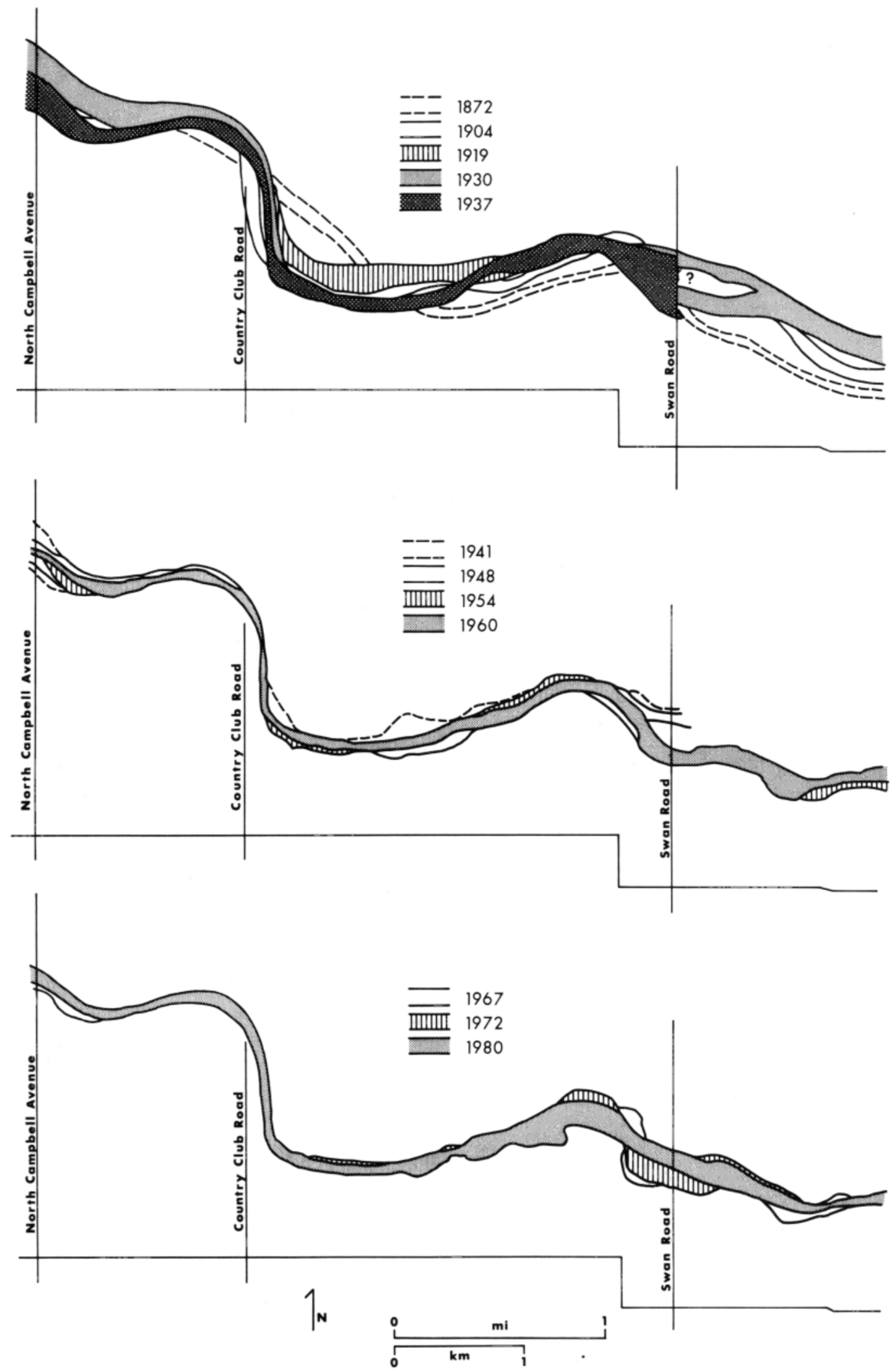

Fig. 4. Historical channel locations along Upper Rillito Creek (shown in Figure 1). Data sources given in Table 2.

the period between the dates of the two maps, tally the number of cells for each row/column (see Table 1 as an example). Using hydrologic records and the annual flood series, determine the ranks, the return intervals, and the sum of return intervals for the years covered by the transition matrix $\sum_{t=1}^{n} r$.

6. Determine the observed probability of erosion for each type of cell in the transition matrix by dividing the total 

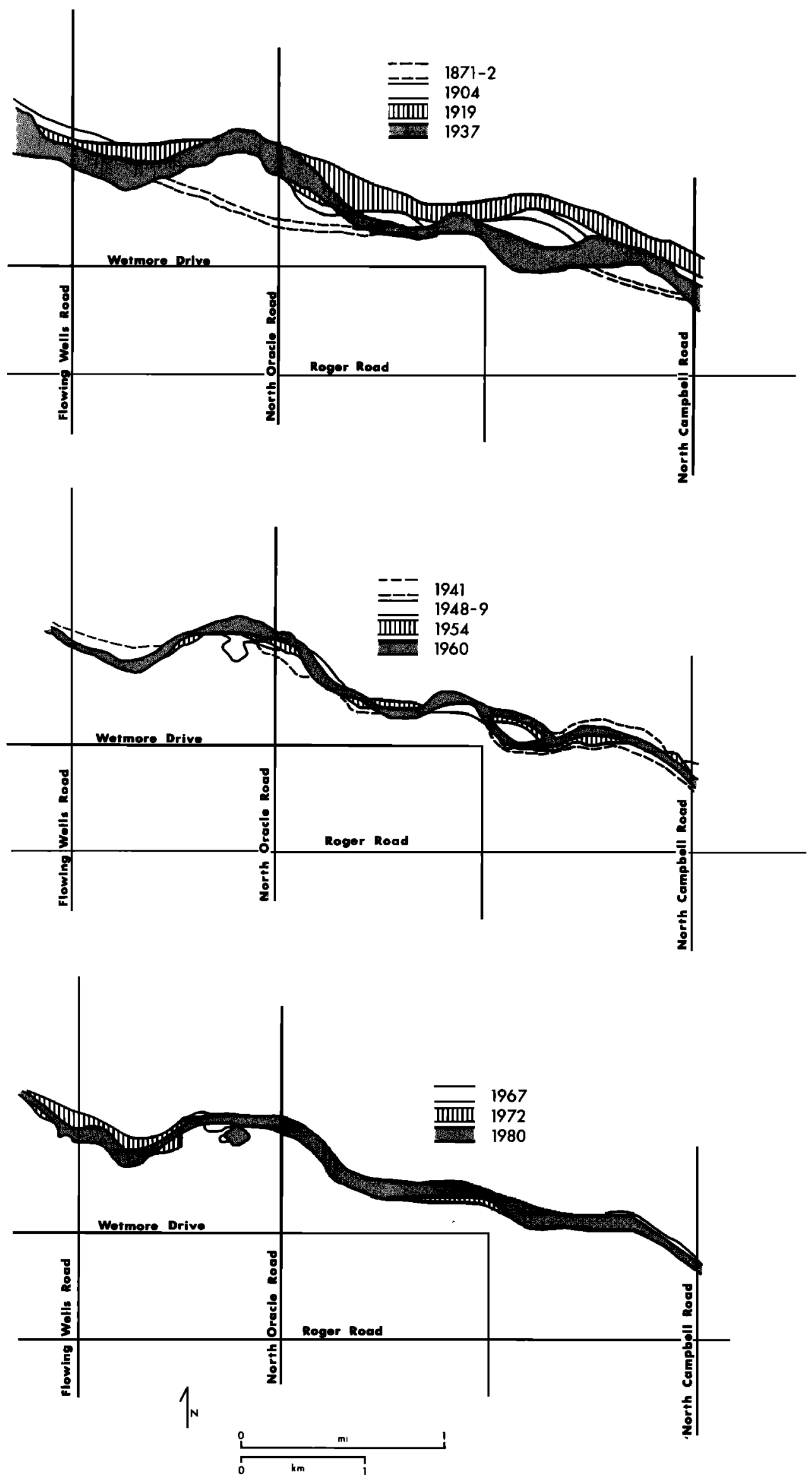

Fig. 5. Historical channel locations along Lower Rillito Creek (shown in Figure 1). Data sources given in Table 2. 

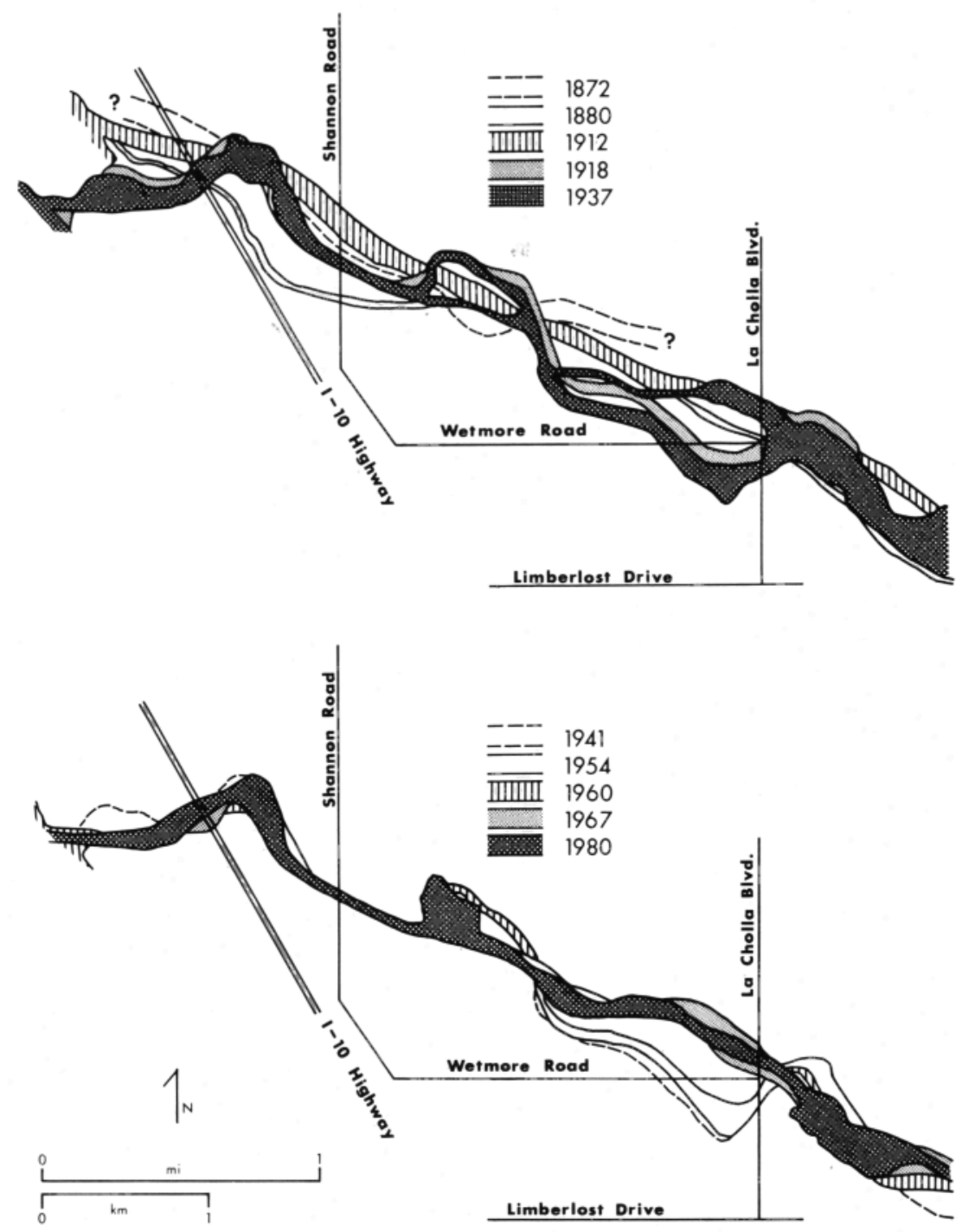

Fig. 6. Historical channel locations along Lower Rillito Creek (shown in Figure 1). Data sources given in Table 2.

number of cells at each row/column intersection into the number that were eroded to determine the observed probability of erosion $\left(P_{i, j}\right)$.

7. Extract from the matrix ordered pairs for probability of erosion $\left(P_{i, j}\right)$, distance laterally to nearest channel $\left(d_{l}\right)$, distance upstream to the nearest channel $\left(d_{w}\right)$, and the sum of the return intervals of the annual floods $\left(\sum_{t=1}^{n} r\right)$. The maximum number of such sets from each matrix in the present study is 16; zero members are discarded.

$$
i \text {. }
$$

8. Repeat steps 3-7 for a different time period, generating another pair of maps, another transition matrix, and another series of ordered pairs of $\left(P_{l, j}, d_{l}, d_{w}, \sum_{=1}^{n} r\right)$. Repeat the process until the historical record is exhausted.

9. Using the ordered pairs of $\left(P_{i, j}, d_{l}, d_{u}, \sum_{t=1}^{n} r\right)$, analyze equation (3) by standard least squares method for the empirical constants that characterize the stream.

10. Using equation (2) and the empirically defined constants, calculate the probability of erosion for each cell of the most recent map of the subject area for a given period. The sums of return intervals for the annual floods may be randomly simulated or dictated.

11. Using equation (2) with its newly defined constants, calculate the probability of erosion for each cell. Map the values to create a spatial representation of the erosion hazard.

\section{Study AREA}

The development and testing of experimental techniques for the assessment of probable damage from erosion by unstable semiarid region channels demand particular characteristics of a study stream. Rillito Creek located on the northern edge of Tucson, Arizona, provides a useful test case for the following reasons (Figure 2). It demonstrates a variety of stable and unstable conditions across space and through time. The stream is large enough to provide enough cells for analysis (476 on the lower reach) but not so many as to overwhelm the experiment. The historical documentary record permits definition of the locations of all or part of the channel for the following years: 1871, 1872, 1880, 1904, 1907, 1912, 1918, $1919,1930,1937,1941,1946,1948,1949,1950,1953,1954$, $1959,1960,1965,1967,1971,1972,1979$, and 1980 (see acknowledgments for sources). The hydrologic record is also lengthy (Figure 3). Extensive engineering research [Simons, $L i$ and Associates, 1981] and geomorphic research [Pearthree, 1983] are available as a comparative backdrop for probabilistic studies.

Rillito Creek is a stream representative of water courses throughout the Basin and Range Province of the interior southwestern United States and northwest Mexico (see Hunt 


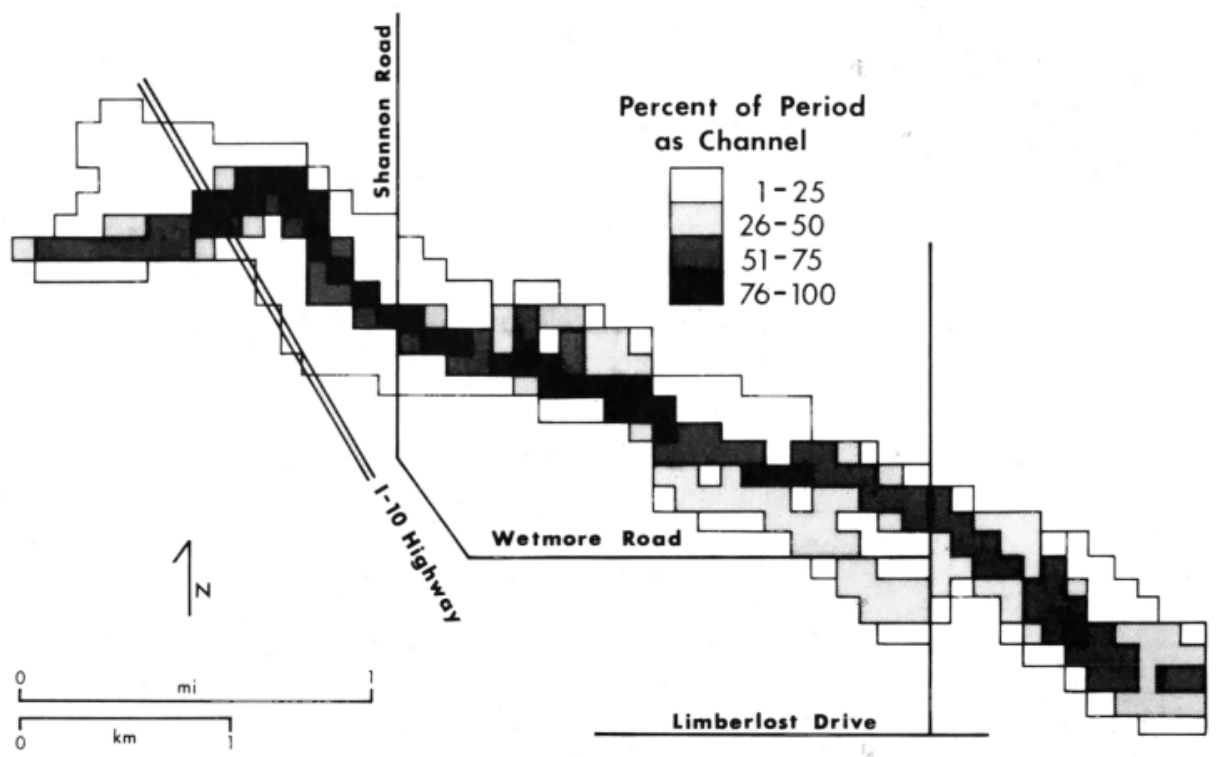

Fig. 7. Grid cell map of Lower Rillito Creek (location of reach shown in Figure 1, some original locations shown in Figure 5), for the period 1871-1978. Percentages shown by shading represent the percent of the 107-year period that each cell was occupied by channel.

[1974] for a regional overview). It is formed by the confluence of Tanque Verde Wash and Pantano Wash, streams with headwaters in mountains rising to elevations of $2,790 \mathrm{~m}(9,160$ $\mathrm{ft})$. The Rillito flows $18.4 \mathrm{~km}(11.5 \mathrm{mi})$ through an alluviumfilled fault-block valley to its junction with the region's master stream, the Santa Cruz River, at an elevation of $670 \mathrm{~m} \mathrm{(2200}$ ft). For a review of the geologic setting see Wilson et al. [1960] and Nations and Stump [1981]. At its mouth the Rillito drains an area of approximately $2378 \mathrm{~km}^{2}\left(918 \mathrm{mi}^{2}\right)$ that is dominated by porous soils and Arizona upland subdivision vegetation, mostly saguaro cactus, palo verde trees, and creosote bush [Brown et al., 1980]. The annual rainfall over most of the basin is $20-40 \mathrm{~cm}$ (8-16 inches) [Sellers and Hill, 1974].

\section{Channel Changes}

A review of historical channel locations along the Rillito Creek indicates that an unstable period extended from 1871 (and probably earlier) to about 1937 . Instability has not been constant through time or space (Figures 4-6). Prior to 1890 the channel was flowing on an upper surface of alluvial fill, but in the period after 1890 the Santa Cruz River became entrenched during a series of floods [Hastings, 1958]. Headward erosion of the arroyo from the master stream resulted in the entrenchment of Rillito Creek in several reaches, converting it from a shallow marshy stream to an arroyo. Once this conversion was complete (by about 1937) instability was manifested primarily by bank erosion. Smith [1910] attributed the entrenchment of Rillito Creek to overgrazing and haymaking associated with an army post established at the junction of Pantano Wash and Tanque Verde Creek in 1872. He reported a major flood in 1881 but no channel instability until the 1890's (see Cooke and Reeves [1976] for further analysis). The economic significance of these events is that after entrenchment (especially in the lower reach) the arroyo is so large that it can contain even the 500-year flood (U.S. Army Corps of Engineers, Los Angeles District Office, unpublished overflow calculations, 1983). Generally the 1871-1937 maps reveal more instability than the 1937-1978 maps. Lower Rillito Creek has consistently been more unstable than the upper and middle reaches. Extensive bank protection efforts have been successful in stabilizing the middle and upper reaches since 1960 . All three reaches have shown decreasing instability over the 107-year record, probably in response to generally smaller annual floods since 1941 (Figure 3). Floods in 1983 interrupted the general trend.

The upper and middle reaches have modest degrees of locational instability (Figures 4 and 5), while the lower reach migrated over substantial areas (Figure 6). A comparison of Figures 4, 5, and 6 shows the spatial variation in instability among the reaches. Because the lower reach has exhibited greater instability, it is the focus of the remainder of this paper.

A cell map summary of channel locations for the Lower Rillito reveals the spatial variation in channel stability from 1871 to 1978 (Figure 7). The I-10 Highway and Shannon Road crossings appear as parts of a stable zone, but the entire eastern portion of the reach shows locational instability. The eastern section has been characterized by more meanders and more midchannel islands than the Shannon Road section.

\section{Results}

Transition matrices similar to the one shown in Table 1 provided data for the empirical definition of the constants in (2) and (3). Three matrices for the relatively unstable period

TABLE 2. Solution for the Function $P_{i, j}=a_{0}\left(d_{t}\right)^{b_{1}}\left(d_{w}\right)^{b_{2}}\left(\sum_{t=1}^{n} r\right)^{b_{3}}$ for Lower Rillito Creek

\begin{tabular}{|c|c|c|}
\hline Statistic & $\begin{array}{l}\text { For Period } \\
1912-1937\end{array}$ & $\begin{array}{l}\text { For Period } \\
1937-1978\end{array}$ \\
\hline$r$, coefficient of correlation & 0.728 & 0.785 \\
\hline$r^{2}$, coefficient of determination & 0.530 & 0.617 \\
\hline $\begin{array}{l}S, \text { standard error of the estimate } \\
(\log \text { form) }\end{array}$ & 0.317 & 0.276 \\
\hline$F$, regression $F$ ratio & 4.136 & 10.731 \\
\hline$p$, confidence interval & 0.034 & 0.0004 \\
\hline$n$, number of cases & 15 & 24 \\
\hline$a_{0}$, coefficient & 7092 & 3960 \\
\hline$b_{1}$, exponent & -0.893 & -1.432 \\
\hline$b_{2}$, exponent & -0.894 & -0.912 \\
\hline$b_{3}$, exponent & -0.249 & 0.222 \\
\hline
\end{tabular}




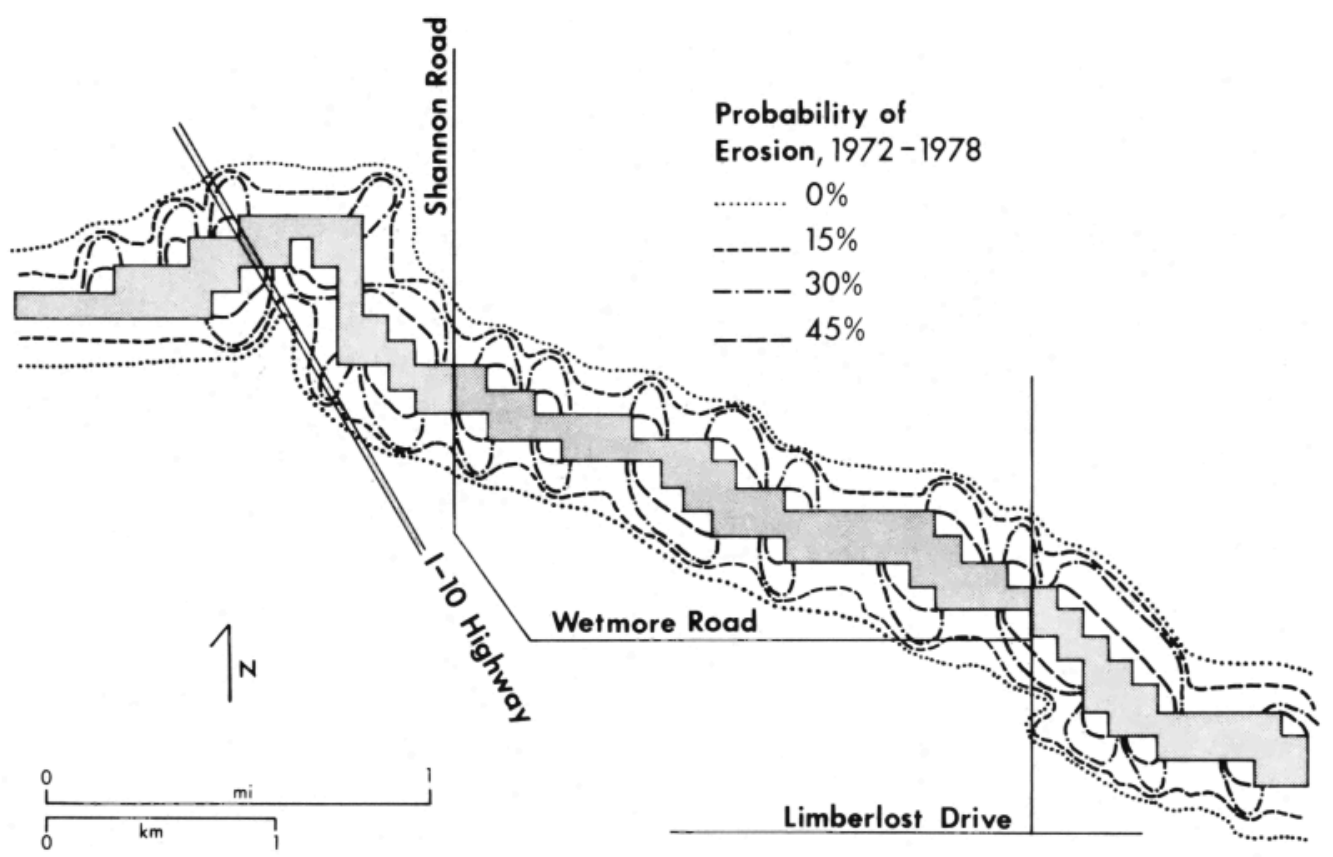

Fig. 8. Erosion probability map of Lower Rillito Creek for the test period 1972-1978.

depicted changes for the periods 1871-1912, 1912-1918, and 1918-1937 (the 1871-1912 period could not be used due to lack of hydrologic data). Seven matrices for the more stable period depicted changes for the periods 1937-1941, 1941$1949,1949-1954,1954-1960,1960-1967,1967-1972$, and 1972-1978. Availability of historical data constrained the choice of periods, and during later times, shorter periods, though available in the historical data, revealed little change, did not add information to the analysis, and were eliminated.

The calculation by least squares methods of (2) and (3) provided the results in Table 2 . The regression statistics show that variation in the probability of erosion for a given cell is reasonably accounted for by the two location variables and the annual flood series variable. The functions are not perfect predictors because of complex variables that are not accounted for, a usual problem when dealing with fluvial systems [Leopold et al., 1964, p. 274]. Predictability might be enhanced by inclusion of factors describing bank materials, soils, vegetation (in the channel, on the banks, and on the alluvial surface), sediment discharge in addition to water discharge, and the influences of engineered features of the channel and nearchannel environment. The expense of including additional variables may not be worth the probable minimal improvement in the final predictive model.

The results shown in Table 2 indicate the expected distance decay: the probability of erosion of a cell declines when distance from the channel increases (indicated by negative ex-

TABLE 3. Results of Operation of the Complete Algorithm

\begin{tabular}{cc}
\hline $\begin{array}{c}\text { Number of } \\
\text { Projected Years }\end{array}$ & $\begin{array}{c}\text { Number of } \\
\text { Cells Eroded }\end{array}$ \\
\hline 2 & 9.2 \\
5 & 13.6 \\
10 & 17.5 \\
25 & 21.0 \\
50 & 27.4 \\
\hline
\end{tabular}

ponents, $b_{1}$ and $b_{2}$ ). During the more unstable period between 1912 and 1937 this decline was less abrupt than in the more stable 1937-1978 period (note especially the $b_{1}$ exponents for the two periods). In the earlier period, distance from a cell laterally to a stream channel was about as important as its distance upstream to a channel (indicated by nearly equal $b_{1}$ and $b_{2}$ values). In the later period, however, the importance of lateral distance declined more rapidly than the distance upstream to nearest channel $\left(b_{1}\right.$ greater than $\left.b_{2}\right)$. This arrangement probably represents a condition where in relatively straight reaches there is some erosion but it does not extend more than about $200 \mathrm{~m}$ (650 ft) from the original channel location. Meander migration, however, has been active and has eroded many cells. The value of exponent $b_{3}$, associated with the sum of return intervals for the annual flood series, probably should be positive as shown for the 1937-1978 period. In the 1912-1937 period only two values are available for the variable, so the negative $b_{3}$ value is not meaningful.

As a test of the accuracy of the algorithm and its functions, equation (2) with constants defined empirically for the 19371972 period was used to predict the 1978 map using the 1972 map as a starting condition. The resulting erosion probability map (Figure 8) identifies hazardous zones of instability and other more stable areas. Erosion during the test period was confined to those cells that were mapped with the highest probability of erosion except for six cells apparently influenced by gravel mine operations.

Table 3 summarizes the results of solving equation (2) for $P_{i, j}$ and then applying the calculated values to a transition matrix representing the 1978 channel system as a simulation. The sums of recurrence intervals used in the $2,5,10,25$, and 50 -year calculations were generated on a random basis, but there were no simulated floods with return intervals greater than the period under investigation. Thus the 50-year calculations used a single 50-year flood, two 25 -year floods, and so forth. The total number of cells lost to erosion increases rapidly as the time period under consideration increases from 2 to 
10 years, but further increases in time brings about only modest increases in number of cells eroded.

\section{LiMITATIONS}

Although the example of Rillito Creek indicates that the probabilistic approach to erosion damage assessment is possible, a number of reservations are clear. The method proposed in this paper is still experimental, and it requires further testing in other areas. Certain specific aspects of the method remain technically uncertain: optimum cell size, probably related to channel width, is unknown, as are many of the statistical properties of the distance measures when they are associated with meandering versus braided channels. Also, the method is implicitly based on established trends of system channel and assumes the continuation of those trends. Similar assumptions of system stationarity are common in deterministic engineering and hydrologic-based models, but the problem remains that stationarity may not be assumable.

The length of record of historical channel locations is critical in establishing a series of probabilities for the erosion of cells. If the record is too short, short-term aberrations in system behavior may be overrepresented. Fortunately, the record of the annual flood series for Rillito Creek shows no extremely large events, but this may be an issue in other applications. It appears that at least $\mathbf{5 0}$ years of record is desirable with channel locations known once or twice during each decade. For most rivers and streams in urban or agricultural areas such a record is likely to exist because aerial photography was introduced in many areas by the middle 1930's. Historical maps usually supplement aerial photography for pre-1930 conditions.

When long-term predictions are generated, the probabilistic method outlined above is based on simulations utilizing random numbers compared to given probabilities to generate a series of flood events. Therefore the exact course of events in changing channel locations is not a primary product of the method. The most stable product is probably the number of cells lost rather than the locational identity of those cells.

Finally, the method outlined above is designed to accommodate the continually eroding condition along Rillito Creek. When a cell adjacent to the existing channel is eroded, no concommitant deposition is predicted for the opposite bank, and the channel widens. Deposition associated with erosion and prediction of migration of a channel of constant width are not features of this method.

\section{CONCLUSIONS}

The practical planning implication of a probabilistic approach to predicting channel migration and erosion is that it permits the economic assessment of potential losses under no project conditions that heretofore could not be assessed. Given present land values along the lower Rillito Creek (about $\$ 10,000$ per acre), the erosion of 27.4 cells over a projected 50-year period represents an economic loss of over $\$ 675,000$. Extended to the entire Rillito Creek, erosion losses exceed $\$ 2$ million. These values are 5 times the losses projected by the U.S. Army Corps of Engineers for inundation damages during a similar period (U.S. Army Corps of Engineers, Los Angeles District Office, unpublished data, 1983, courtesy J. Manti).

In summary, deductive approaches to river channel behavior can be supplemented by probabilistic analyses that rely on grid cell maps of the near-channel landscape. The most important advantage of the grid cell map is that it can be used to reflect channel migration and erosion through empirical functions summarizing the past observed behavior of the channel. Geographic analysis of the likelihood that a given parcel of land will experience erosion is based on the fundamental concept of distance decay away from a neighboring channel and the magnitude/frequency of flood events. Assuming that system operation possesses stationarity, the functions can be used to extend past experience to predict probable future behavior. Probabilistic approaches given here do not replace deterministic geomorphologic, hydrologic, or engineering functions that describe physical channel processes: they add a better understanding of the geographic processes of changing channel locations.

Acknowledgments. Research reported in this paper was financially supported by the Phoenix Office of the U.S. Army Corps of Engineers, but the opinions expressed are solely the author's and do not necessarily reflect the policy of the funding agency. W. Andrew Marcus collected much of the data, and Michelle E. Behr was the cartographer. Sources of documentary evidence of historical channel locations included the Arizona Historical Foundation (Tucson), map collection of Arizona State University (Tempe), map collection of the University of Arizona (Tucson), Office of Arid Lands Studies of the University of Arizona (Tucson), Pima County Flood Control District (Tucson), Tucson Department of Zoning, U.S. Geological Survey (Tucson and Reston, Virginia), Bureau of Land Management (Phoenix), Soil Conservation Service (Tucson), and the Arizona State Lands Department (Phoenix).

\section{REFERENCES}

Brown, D. E., C. H. Lowe, C. P. Pase, A digitized systematic classification for ecosystems with an illustrated summary of the natural vegetation of North America, Gen. Tech. Rep. Rm U.S. For. Serv., $R m-73,1980$.

Cliff, A. D., and J. K. Ord, Spatial Processes: Models and Applications, Pion, London, 1981.

Cooke, R. V., and R. W. Reeves, Arroyos and Environmental Change, Clarendon, Oxford, 1976.

Corps of Engineers, Final Report to Congress, the Streambank Erosion Control Evaluation and Demonstration Act of 1974, Section 32, Public Law 93-251, 9 vol., U. S. Army Corps of Engineers, Washington, D. C., 1981.

Glover, R. E., Dispersion of dissolved or suspended materials in flowing streams, U.S. Geol. Surv. Prof. Pap., 433-B, 1964.

Graf, W. L., Distance decay and arroyo development in the Henry Mountain Region, Utah, Am. J. Sci., 281, 1541-1554, 1982.

Gregory, K. J., River Channel Changes, John Wiley, New York, 1977.

Hastings, J. R., Vegetation change and arroyo cutting in southeastern Arizona during the past century: A historical review, in Arid Lands Colloquia, pp. 24-39, University of Arizona, Tucson, 1958.

Hughes, D. J., Rates of erosion on meander arcs, in River Channel Changes, edited by K. T. Gregory, pp. 193-205, John Wiley, New York, 1977.

Hunt, C. B., Natural Regions of the United States and Canada, W. H. Freeman, San Francisco, Calif., 1974.

Leopold, L. B., M. G. Wolman, and J. P. Miller, Fluvial Processes in Geomorphology, W. H. Freeman, San Francisco, Calif., 1964.

Nations, D., and E. Stump, Geology of Arizona, Kendall/Hunt, Dubuque, Iowa, 1981.

Pearthree, M. S., Channel Change in the Rillito Creek system, southeastern Arizona: Implications for floodplain management, M. S. thesis, Univ. of Ariz., Tucson, 1983.

Sellers, W. D., and R. H. Hill, Arizona Climate, 1931-1972, University of Arizona Press, Tucson, 1974.

Shen, H. W., Modeling of Rivers, John Wiley, New York, 1979.

Sheppard, E. S., Geographic potentials, Ann. Assoc. Am. Geogr., 69, 438-447, 1979.

Simons, D., and F. Senturk, Sediment Transport Technology, Water Resources Publications, Fort Collins, Colo., 1977. 
Simons, Li and Associates, Inc. Sediment transport analysis of Rillito River and tributaries for the Tucson urban study, draft report, Fort Collins, Colo., 1981.

Smith, G. E. P., Groundwater supply and irrigation in the Rillito Valley, Ariz. Agric. Exp. Stn. Bull., 64, 81-242, 1910.

Wilson, E. D., R. T. Moore, and R. T. O'Haire, Geological map of Pima and Santa Cruz counties, Arizona, Ariz. Bur. of Mines, Tucson, 1960.
W. L. Graf, Department of Geography, Arizona State University, Tempe, AZ 85281.

(Received September 16, 1983;

revised February 13, 1984;

accepted February 23, 1984.) 